\title{
Applying Succession Management Benefits For Leadership Continuity
}

\author{
Maisie Reid, (E-mail: qnv13@bellsouth.net), Nova Southeastern University
}

\begin{abstract}
Faced with increasing numbers of employees retiring and dwindling replacements, corporations are implementing succession management programs at all levels of the organization to build structural leadership for internal employee advancement, and ensure leadership continuity. There is a need for succession planning management in public service agencies. This article discusses succession management benefits, and incorporation of strategic human resource management tools for leadership continuity in anticipation for retirements and replacements, and suggests future research directions.
\end{abstract}

\section{INTRODUCTION}

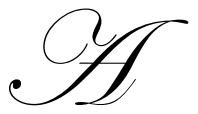

fter anticipating significant retirements in the Federal Senior Executive Service beginning in 1994, the National Academy of Public Administration (NAPA) began a serious look at succession planning in the public sector; and noted that public service agencies ignored succession planning (Schall, 1997). Today, government leaders as well as practitioners are concerned about the number of people retiring and taking their expertise, specific job skills, and knowledge about the organization with them. Deputy Assistant Secretary of Defense for civilian personnel policy stated that, "Agencies are concerned not just about people retiring, but about the great numbers in which they'll be leaving and the experience they'll be taking with them" (Adelsberger, 1998, p. 25). Ehrenhart (1999) reported that older government workers between ages 45 and 64 have increased from 36.8 percent in 1994, to 41.7 percent in 1998 (Green, 2000). That means overall, "Between 1998 and 2008, workers age 45 and older will grow from 33 percent to 40 percent of the U.S. workforce, while those between the ages of 25 and 44 will plummet from 51 percent in 1998 to 44 percent in 2008" (Rothwell, 2002, p. 32).

At a Senate Government Affairs sub-committee hearing in 2000, the Comptroller General said "human capital planning is ineffectual and could end up on General Accounting Office's (GAOs) list of the worst management problems in the federal government" (p. 109). Similarly, twelve years ago the National Commission on Public Service echoed the Comptroller General concern by stating that there was a "quiet crisis" in civil service management. The emerging crisis stems from an aging workforce with many experienced employees retiring, and an extremely competitive job market. The GAO responded to the crisis by publishing guides on human resource planning processes, while the Comptroller General offered suggestions to improve recruiting efforts, and the Office of Personnel Management wants government to "engage in the war for talent" (p. 109) by studying gaps in skills and needs, and developing action plans to fill those needs (Saldarini, 2000).

As experienced employees retire, public service agencies are confronted with competition for top talent from both national and international job market (Saldarini, 2000); this has resulted in lack of qualified replacements (Lavigna and Hayes, 2004). In addition, the legacy of restructuring, privatization and outsourcing during the 1990s, which provided considerably saving, has sapped knowledge from agencies (Saldarini, 2000). According to Stern (1997) the typical 20-year career building cycle has morphed into 20-month skill-building process. Besides that, more qualified workers are entering the workforce requiring above entry level pay; causing public service employers to realize employees' tenure will be shorter. Additionally, "as the average age of the workforce shifts upward, the average length of time an employee stays in a job keeps shrinking" (Green, 2000, p. 436). 
Rainey and Wechsler (1988) suggested that, "Whether one adopts a broad or more specific approach to organizational performance and productivity, effective transition management is essential to achieving positive results"(Schall, 1997, p. 5). Forward thinking private sector organizations are linking succession management to strategic human resources tools to ensure leadership continuity, and maintain organizational performance (Huang, 2001; McManis and Leibman, 1988); and although scare, research shows the public sector is inching in that direction (Green, 2002; Kim, 2003; Lynn, 2001). Because public sector is slow in adopting succession management, this article serves to emphasize succession management benefits, and delineate strategic human resource tools to identify and develop top talent for leadership retention in preparation for retirements and replacements.

\section{TRANSITION TO SUCCESSION MANAGEMENT}

Succession planning facilitates the identification of personnel who assume certain key organizational positions or fill vacancies (McConnell, 1996). Dessler (2000) defined succession planning as an ongoing process to ensure individual career development to optimize the organization's current and future needs (Huang, 2001). In theory, the concept involves matching the organization long-term leadership requirements with qualified candidates (Kesner, 1989). In public service agencies, human resource professionals shied away from any form of succession planning, for fear there would be allegations that the merit system principles were not being enforced. If at all succession planning was discussed, the focus was on filling one position, instead of preparing employees for future leadership positions (Green, 2000).

Private sector succession planning had connotations of secret organizational charts with names of key executives penciled in (Patton, 2001). Although many organizations are evolving their succession planning efforts, the process does not deliver full potential to address globalization, restructuring, and client expectations. Assumptions that guided succession planning have changed. No longer is succession planning grounded in a stable business environment where individuals remain in one corporation over one's entire career life cycle. Caudron (1996) wrote, "In an era of continual job hopping and constant change... successful companies don't view [succession planning] as a matter of executive replacement- it's one of leadership development" (Kur and Bunning, 2002, p. 761). Today's dynamic environment with social and economic complexities, global competition, and business discontinuities require succession planning to encompass a broader scope of integrated leadership development systems (Ostrowski, 1968; Leibman, Bruer, and Maki, 1996; Metz, 1993; Wallum, 1993).

To make succession planning more germane to current business environment, organizations have adopted succession management ongoing and integrated processes emphasizing more flexible and dynamic approach for developing strong leadership teams (Leibman, Bruer, and Maki, 1996). Nardoni (1985) and Dolan (1987) defined succession management as an organized method of identifying and developing talented individuals in organizations to ensure continuity of leadership; while lowering employee turnover, and improving staff morale by placing most qualified candidates in key positions (Johnson et al, 1994). For example, to meet global demands, Exxon improved global representation of leadership positions by emphasizing the importance of multi-lingual competence as criterion for management assignments. Similarly, Westinghouse revised its training and development process to meet changing societal expectations (Leibman, Bruer, and Maki, 1996).

\section{SUCCESSION MANAGEMENT BENEFITS}

Succession management offers flexible and dynamic approach to strong leadership, and adds value to team performance. With teams playing more dominant role in organizations, utility of succession planning focus on the individual diminishes. Increasingly, organizations rely on teams of people working in flatter organizations with greater authority and accountability to make decisions. Succession management shifts the focus in organizations "from a narrow goal of developing individual leaders to that of developing the leadership function and team leaders who will lead the organization through significant change"(Kur and Bunning, p. 762, 2002). The process identifies and develops existing personnel with leadership potential, and "focus on creating and stocking pools of candidates with high leadership potential; not identifying individuals for specific jobs" (Patton, p. 19, 2001). 
A second benefit derived from succession management is continuation of efforts involving several interrelated strategic planning activities. Making succession management part of strategic planning is designed to facilitate effective execution of the organization's strategic plan (Patton, 2001). As part of the organization's strategic planning process, in order to plan for future leadership needs, managers must have clear understanding of the organization's mission and goals and objectives. Goals and objectives are specific results the organization hopes to achieve, and therefore, represent the parameters for future strategy development and leadership needs (Kesner, 1989; McConnell, 1996; Ostrowski, 1968). When succession management is preceded by strategic planning process (Kesner, 1989), it reflects the organization's strategic intent, takes into account realistic strategic scenarios, and underscores the need to build internal resources (Burdett, 1993).

As an integral part of strategic planning activities and human resource system, succession management encourages stability in the organization, and dedication in attaining the organization strategic goals and objectives. According to Pattan (1986), strategic management succession plans enable organizations to specify managerial functions and performance standards (Huang, 2001). Similarly, NAPA (1997) leadership development research noted that integrating succession management into public organization's strategic plan was a logical step to be taken under the Government Performance and Results Act (GPRA) of 1993 (Kim, 2003). By getting top-level executive support (Ostrowski, 1968), successful succession management embodies all levels of management (McConnell, 1996) who sponsors the concept and sells the idea to the entire management team (Fleischmann, 2000).

Other benefits are creating pools of candidate with high leadership potential. Succession management cultivates and develops potential leaders within the organization. It maintains the organization momentum, helps retain talent, and provides solid support for promotion internally. Succession management not only provides pools of candidate, but it places most qualified candidate in key positions, lowers turnover rates, and improves employee morale. Because employees have opportunities for advancement within the organization, they believe in serious organizational commitment to leadership development, which is important to employee morale and individual motivation (McConnell, 1996). According to Catholic Health East Vice President, succession management helps attract talent because people know there are broad opportunities for anyone in the executive track (Rollins, 2003).

Succession management ensures minimal disruption in the organization because employees are qualified to move into key positions when those positions are vacated (Patton, 2001). The process establishes broad base leadership ready to take on new challenges, and avoid disruption as a result of ill-timed promotions and inadequately prepared managers. Succession management addresses both recruitment and retention by attracting people to the organization and retaining them; therefore, making it easier to fill positions internally (Rollins, 2003). Ultimately, these benefits reflect the organization's commitment to employee development and job advancement (Johnson et al, 1994). Additionally, succession management provides greater assurance that critical positions in the organization are protected against loss of organizational knowledge (Fleischmann, 2000), and retain employees who are engrained in the organization's culture and precepts.

\section{SUCCESSION MANAGEMENT PROCESS}

In the past, public service agencies have not paid sufficient attention to strategic succession, even in terms of executive leadership (Schall, 1997). The Institute of Public Management Association (IPMA) suggested that public agencies may not always have the wherewithal to establish succession programs; however, they can avoid pitfalls if strategic human resource management tools such as candidate selection and assessment, and career development programs are employed (Kim, 2003). To utilize succession management benefits, the process incorporates a constellation of strategic human resource management tools to identify and develop talented employees. It begins by selecting participants and assessing their competencies. The next phase develops potential leaders through leadership development techniques such as assignment opportunities, training procedures, mentoring, and job performance feedback. 


\section{Selecting Participants}

According to Metz, the first phase of the selection process starts by identifying the organization strategic mission. This is a shift away from the "replacement charting" process of the past, in which each position had a slate of ready candidates identified regardless of what capabilities were needed for strategic success (p, 32). Upon identification of the organization strategic mission, the first step is defining leadership competency to evaluate existing positions (Metz, 1998; Lynn, 2001). The next step is identifying the top 10 or 15 percent management positions that are most critical; that is, determine knowledge, skills and abilities necessary for each position, and identify candidates for those positions (Hall, 1986). Once established, these competencies become part of each candidate identification process (Kur and Bunning, 2002), and touchstones for leadership development (Lynn, 2001).

A recent succession management survey revealed 100 Fortune 500 companies practiced leadership competencies. Leibman Associates conducted the survey and reported that approximately two-thirds of those surveyed developed explicit leadership competencies that serve to inform the succession management process. Similarly, Boeing, 3M, NationsBank and Westcoast Energy agreed that leadership competencies provide common language discussion and constructive evaluation of candidates (Cope, 1998). For example, selection criteria looks at what leadership traits the organization consider fundamental, and what traits candidates possess upon entering the program. The selection process finds a good match between immediate and future role demands and the candidates' personality such as assertiveness, empathic towards others and open to feedback, stay focused under pressure, and general intelligence (Pernick, 2001).

The selection process identifies skills needed for each job. Although many organizations pre-determine job descriptor skills, these skills identify only technical and professional skills needed to perform the job. Soft skills such as communication, inter-personal relationships, political sensitivity, and leadership ability are crucial because they dictate options available in succession management (Fleischmann, 2000). Selection contributes to strategic and organizational flexibility by providing decision-makers access to pools of managerial talent. Additionally, selection is the objective data that provides for making managerial assignments. According to Flanagan (1951) the focal job is defined in terms of its critical task components and relative importance. Hence, requisite traits and abilities are inferred from the tasks, and the extent to which these are present in the candidate that is being measured (Kerr and Jackofsky, 1989).

In addition, there is increased recognition that selection decisions incorporate developmental considerations. According to Friedman (1986) survey on succession planning practices, some organizations have begun to focus on what a position can offer as developmental experience. This means that, the succession event offers an opportunity for someone to learn experientially, not just filling a position. Additionally, Friedman found that the more frequently participants' needs informed organizational decisions, the organization reputation and financial performance improved. Similarly, Ruderman and Ohlott (1994) survey reported that 31 percent of executive promotions related to executive groomed for key positions as further advancement, or given an opportunity in order to prevent derailment, related to developmental considerations (McCauley, Eastman, and Ohlott, 1995).

\section{Assessment Competency Skills}

Assessment is another strategic human resource tool that evaluates individual planning, organizing, decisionmaking and leadership ability. From an organizational perspective, assessment serves as needs assessment to determine training or other appropriate development measures. 360-degree feedback assesses leadership strengths and need for professional growth (Rothwell and Wellins, 2004). Environmental scanning, organizational analysis, and future-oriented activities are other techniques for assessing future needs (Lynn, 2001). For example, data collection information provides insight into employee's style and motivation (Pernick, 2001), and requirements for specific position both current and future (Rollins, 2003). Most popular is assessment centers variety of testing techniques including job simulation exercises, whereby candidates demonstrate job related dimensions of work characteristics in job simulation exercises replicating important situations that occur on the job (Joiner, 2002). Trained observers rate performance on simulation and exercises (Pernick, 2001), and scoring within performance dimensions measurement context is important because measurement has a strong effect on scores employees achieve (Joiner, 2002). 
Although majority of public sector assessment centers are used for law enforcement and fire service promotion, centers are valuable for career development, organizational development and succession planning tools. Instead of using dimensions and exercises related to specific target job or job level, dimension selection and exercise development becomes several levels of management and skills, and situations common to all or highest management levels. The focus shifts from accuracy of "scores" to "quality of the assessor comments," and the goal is quality performance feedback and developmental suggestions for every candidate. "Succession planning information is obtained by comparing candidate skill profile to future job requirement needs." Where skills are lacking in candidate' profile, decisions must be made whether those skills can be developed quickly to meet the organization needs or recruit from outside. If employees are chosen internally, assessment center results should be viewed as snap shot for career development plans to close skill gaps (Joiner, 2002, p. 180).

In succession management context, assessment answers if employees have reached leadership potential, what obstacles are preventing career growth, and most suitable position for employee. Gap analysis evaluates every position and employees in those positions and compares critical skills need with employees' skills and experience. Deficit in gaps are addressed to ensure minimum level of competency is maintained in each critical position (Fleischmann, 2000). Assessment not only provides direction for career development, but it brings talent to the surface, and forces re-evaluation of long-range potentials of employees who may not be suitable for certain positions (Ostrowski, 1968). Using survey data, employees prepare detailed individual development plan and review it with management who determines employees' direction, the next potential position, and skill training needs (Pernick, 2001).

\section{Assignment Opportunities}

Selection of activities and assumptions regarding career development is based upon employees' skills gap. To fill the gap between desired and actual skills, some organizations assign managers new responsibilities outside of their primary area of expertise. That is, it's far more effective to pair classroom training with real life exposure and a variety of jobs and bosses technique such as job rotation and special assignments (Fulmer and Conger, 2004). Columbus Regional Healthcare System practices assignment opportunities to prepare their leaders. According to the Chairman, "We use our talent pool in non-traditional ways to see that we have excellently prepared managers. We might have people move from one management role to another, crossing responsibilities. That's something we didn't do before" (Rollins, 2003, p. 21).

Secondment, another assignment opportunity, is temporary assignment of employees to another part of the organization for a substantial period of time, then bringing back employees to their original position. Secondment fills gaps in host organization by providing unparalleled learning experience for employees when they return to their original position with new knowledge and contacts. Secondment assignment is practiced all over Europe; it involves geographical as well as organizational moves. An example of this approach is called "Back-to-basics" assignments, and is practiced by Disney managers who spend two week each year "on the shop floor," providing direct customer service, working in retail shops, operating rides, and selling tickets. The experience helps keep leaders close to customers, subordinates, and the main function of company business (Kur and Bunning, 2002).

Other forms of assignment opportunities are job swapping and job sharing. Job swapping involves two individuals exchanging positions to learn about other parts of the business, and bring fresh perspectives to new assignments. Job sharing is used to meet personal needs of two individuals. The process is instrumental in maintaining commitment to potential leaders; and job sharing makes it possible to keep two potential leaders (Kur and Bunning, 2002). Examples of these assignments are Pepsi-Cola and Citigroup two year assignments rotation of high potential individuals (Stringer and Cheloha, 2003). According to a survey conducted by McCall et al (1988), 63 percent of managers in the study agreed that providing them with challenging and difficult job assignments effectively hasten and/or accelerate their development (Longenecker and Neubert, 2003).

\section{Training Procedures}

Training plays a critical role in developing potential leaders. Formal training programs emphasize awareness building and teach skills immediately applicable to the job as most valuable learning experience. McCall (1998) 
pointed out that job experiences that are challenging, risky, stressful and visible are most developmental. Similarly, Lombardo and Eichinger (2001) emphasized that people learn most skills on the job. They listed four kinds of experiences as key jobs, important other people, potential hardships, and training courses (Stringer and Cheloha, 2003). According to Guglielmino and Carroll (1979), training consists of formal instructional process which the organization imparts as skills, knowledge, attitudes and social behaviors needed to perform current and future jobs to employees; and develop managerial skills through direct company-specific instructions and general educational experience. Leadership training programs surrounds three categories: technical skills for new career or assignment, interpersonal skills, and conceptual skills for developing and implementing the organization objectives. Other types of leadership development programs are offered by public universities, companies such as MacDonald and Motorola, and United Way, a community agency (Kur and Bunning, 2002).

On the job training consists of in-house classroom training and position rotation for target positions. According to Campion and Cheraskin (1994), cross-training provides additional skills and experiences that are part of the career development plan; and with an arena to learn and develop new skill sets, as well as growth in understanding of inter-relationships between jobs within the organization (Longenecker and Neubert, 2003). An example of workplace learning is partnership with British Telecommunications plc (BT) and Communication Workers Union (CWU). Wood (2000) stated that, "The union has successfully reach members who were written off by the education establishment and given them a second chance. These members have grabbed this opportunity with both hands"(p. 5). This extremely positive response suggests that both employers and employees expect learning opportunities (Stoney, 2002).

Action learning, another training format, alternates between workshops and field experience; the system encourages self-discovery as well as solution to actual business problems (Neary and O'Grady, 2000). The process pulls together a group of high-potential employees to study and make recommendations on a pressing topic. An example of action learning usage is Eli Lilly company bi-annual program that brings potential leaders, line managers and human resources department together to focus on strategic business issue chosen by the Chief Executive Officer (CEO). After a six week session participants analyze what was learned and developed business strategy as a new avenue of growth. This type of action learning serves a dual purpose: "they provide developmental experiences for employees who are forced to look beyond functional silos to solve major strategic problems and thus learn something of what it takes to be a general manager; and they result in a useful work product for the company" (Fulmer and Conger, 2004, p. 40).

Action learning programs enable acceleration members to work in teams as they confront major organizational issues and make recommendations to senior management. PepsiCo practices action learning training by placing pool members into situation where they can experience job challenges, obtain organizational knowledge, develop competencies and overcome executive "derailers" (Byham, 2002, p. 11). Action learning builds individual and organizational competence by allowing team members to learn from each other and from project experience, and at the same time solve business problems (Rothwell, 2002). The projects allow teams to achieve work results, while building individual competencies in needed areas. For example, TRW executives addressed specific business challenges through action learning processes that enabled the company to link theory to practical experiences (Neary and O'Grady, 2000). Other organizations such as Sodexho, Novartis, and Nokia utilize action learning concurrently to solve critical and complex problems, and as key methodology for developing leaders, building teams, and expanding company capabilities (Marquardt, 2004).

\section{Mentoring Participants}

Mentoring another form of career development offers developmental relationship whereby managers nurture, counsel, sponsor and encourage particular subordinates. "Mentoring is considered a mainstream tool for accomplishing many important human resource or staff development goals, including individual career development, management training, encouraging multi-tasking, employee retention and succession planning." Increasingly, due to flatter organizations, mentoring has been deemed an important tool that requires employees to make a "quantum leap in responsibility" which necessitate new forms of preparation for senior roles. Mentoring is considered a useful development intervention tool because there is mutual agreement between both parties, constant feedback, guidance- 
oriented relationship, shared experiences, and long-term continuous learning (Bhatta and Washington, 2003, p. 211). Schneier, MacCoy and Burchman (1988) stated that managers who coach, counsel, mentor, and train their employee enhance their skills and motivation (Tansky and Cohen, 2001).

According to Kramer (1985), mentoring career enhancement roles include sponsorship, coaching, exposure, protection and provision of challenging assignments, and psycho-social functions provide acceptance, counseling, emotional support and role modeling (Joiner, Bartram, and Garreffa, 2004), and is beneficial to protégé as well as the organization. From the organization perspective, mentoring is tied to transfer of culture, including between generations of managers in succession planning. For private sector organizations, mentoring is critical to long-term sustenance, whereas public service agencies, issues of long-term sustenance are not readily apparent (Bhatta and Washington, 2003). However, mentoring could disseminate public agency values and standards across organization when managing successors. Clutterbuck (1991) suggested that mentoring improved recruitment and induction procedures, while Clutterbuck (1991) and Zey (1984), supported leadership development, improved succession planning functions, and organizational commitment (Joiner, Bartram, and Garreffa, 2004).

Mentoring relationship evolves through four stages. At the initiation stage, the mentor and protégé pair off, solidify the relationship, and basic rules are formed. The second stage consists of developmental activities centering on sponsorship, enhancing visibility, and correcting of mistakes before others know the mistakes. In this stage the protégé gains confidence in expertise and a sense of security regarding the mentoring relationship. Physical or psychosocial separation between mentor and protégé occurs in stage three. In stage four, the protégé either pairs with another mentor or becomes a mentor to others (Kerr and Jakofsky, 1989). Mentoring is useful for employees at different career stages. For example, it helps to set a career path, and at more senior stages to solidify credentials, and advancement up the management ladder. Although practiced differently in countries and sectors, evidence of mentoring range from Japan, Singapore, Europe, and Australia to the United States (Bhatta and Washington, 2003).

\section{Job Performance Feedback}

As a vehicle for performance improvement, job performance evaluation provides valuable feedback on employee career growth. Re-administering the 360-degree assessment survey provides comprehensive information on employee leadership growth and competency skills and where there is need further development. For example, after job and training assignments, management should contact participants and discuss how assignments or training fits with employee's development priorities and interests, and growth (Byham, 2002). Depending on employee's career development plan, performance reports should be submitted monthly or agreed upon milestones. The report should be written in narrative form, and include accomplishments, tasks that are behind schedule, and those areas of future concern. The final section of the report should be forwarded to management explaining any consideration that could slow progress or cause delays (Fleischmann, 2000), and career plan revision if needed.

Succession management report must include regular, structured feedback summarizing progress on key competencies and performance of assignments (Abrams, 2004). To make succession management report effective, it should be combined with annual performance appraisal; when both reports are combined, it becomes an ongoing activity (McConnell, 1996). Along with annual performance appraisals, action leaders should build and maintain potential leaders' awareness while performing face-to-face on the job performance review and recommendations on how to improve areas of concern. According to Longenecker and Fink (1997), while performance appraisals can be less effective, well-conducted managerial appraisals have been linked to performance improvement (Longenecker and Neubert, 2003). Feedback should be gathered either internally from staff, or externally from customer surveys, vendors or stakeholders (Stringer and Cheloha, 2003).

\section{CONCLUSION}

Succession management is an ideal private sector model available to public service management. This structured mechanism prepares top talents for leadership continuity in anticipation for retirements and replacements. Succession management multi-faceted approach to leadership development incorporates human resource systems, strategic development of internal talent and performance management. When incorporated to those systems, 
succession management benefits both organization and high potential employees. Demographic data related to baby boomers retiring, and competitive job market are realistic indicators that public agency managers must be committed to implement succession management strategic approach, and utilize human capital effectively and efficiently to enhancement performance and maintain quality customer service.

Areas for future research should address 1) number of public service agencies have implemented plans in anticipation for retirements and replacements, 2) identification and assessment of top talent, 3) level of employee skill gaps and competencies for leadership continuity, and 4) usage of succession management for employee recruitment and retention.

\section{REFERENCES}

1. Abrams, Michael N. (2004). "Market Memo: Five essential elements of an effective succession plan". Health Care Strategic Management, 22(8), 1-4.

2. Adelsberger, Bernard. (1998). Government Executive, 30(1), 25-30.

3. Bhatta, Gambhir, and Washington Sally. (2003). "Hands up: Mentoring in the New Zealand Public Service". Public Personnel Management, 32(2), 211-227.

4. Burdett, John O. (1993). “Crafting tomorrow's leadership today: A practitioner's view of succession and replacement planning”. International Journal of Manpower, 14(8), 23-33.

5. Byham, William C. (2002). “A new look at succession management”. Ivey Business Journal, 66(5), 10-12.

6. Cope, Faye. (1998). "Current issues in selecting high potentials". Human Resource Planning, 21(3), 15-17.

7. Fleischmann, Scott T. (2000). "Succession Management for the Entire Organization”. Employment Relations Today, 27(2), 53-62.

8. Fulmer, Robert M., and Conger, Jay A. (2004). “Developing Leaders with 2020 Vision”. Financial Executive, 20(5), 38-41.

9. Green, Marnie E. (2000). "Beware and Prepare: The Government Workforce of the Future". Public Personnel Management, 29(4), 435-444.

10. Green, Marnie E. (2002). "Ensuring the organization’s future: A leadership development case study". Personnel Management, 29(4), 435-444.

11. Hall, Douglas T. (1986). "Dilemmas in Linking Succession Planning to Individual Executive Learning”. Human Resources Management, 25(2), 235-265.

12. Huang, Tung-Chun. (2001). "Succession management systems and human resource outcomes". International Journal of Manpower, 22(7/8), 736-747.

13. Johnson, Joyce E., Costa, Linda L., Marshall, Sandra B., Moran, Mary Jo, Henderson, and Carol Sue. (1994). "Succession management: A model for developing nursing leaders". Nursing Management, 25(6), 50-54.

14. Joiner, Dennis. (2002). “Assessment centers: What's new?” Public Personnel Management, 31(2), $179-185$.

15. Joiner, Therese A., Bartram, Timothy, and Garreffa, Terese. (2004). "The Effects of Mentoring in Perceived Career Success, Commitment and Turnover Intentions". Journal of American Academy of Business, 5(1/2), 164-170.

16. Kerr, Jeffrey L., and Jackofsky, Ellen F. (1989). “Aligning Managers with Strategies: Management Development Versus Selection”. Strategic Management Journal, 10, 157-170.

17. Kesner, Idalene F. (1989). "Succession Planning”, Credit Magazine, 15(3), 29-34.

18. Kim, Soonhee. (2003). "Linking Employee Assessments to Succession Planning”. Public Personnel Management, 32(4), 533-547.

19. Kur, Ed, \& Bunning, Richard. (2002). "Assuring corporate leadership for the future". The Journal of Management Development, 21(9/10), 761-779. 
20. Lavigna, Robert J., and Hays, Steven W. (2004). "Recruitment and Selection of Public Workers: An International Compendium of Modern Trends and Practices". Public Personnel Management, 33(3), 237 253.

21. Leibman, Michael, Bruer, Ruth A., and Maki, Bill R. (1996). "Succession Management: The Next Generation of Succession Planning". Human Resource Planning, 19(3), 16-28.

22. Longenecker, Clinton O., and Neubert, Mitchell. (2003). "The management development needs of front-line managers: voices from the field". Career Development International, 8(4), 210-218.

23. Lynn, Dahlia Bradshaw. (2001). "Succession Management Strategies in Public Sector Organizations". Review of Public Personnel Administration, 21(2), 114-132.

24. Marquardt, Michael. (2004). "Harnessing the Power of Action Learning”. Training and Development, 58(6), 26-32.

25. McCauley, Cynthia D., Eastman, Lorrina J., and Ohlott, Patricia J. (1995). "Linking Management Selection and Development through Stretch Assignment”. Human Resource Management, 34(1), 93-115.

26. McConnell, Charles R. (1996). "Succeeding with Succession Planning". The Health Care Supervisor, 15(2), 69-78.

27. McManis, Gerald L. and Leibman, Michael S. (1988). "Succession Planners". The Personnel Administrator, 33(4), 24-30.

28. Metz, Edmund J. (1998). "Designing Succession Systems for New Competitive Realities". Human Resource Planning, 21(3), 31-37.

29. Neary, D. Bradford, and O'Grady, Don A. (2000). "The role of training in developing global leaders: A cast study at TRW Inc." Human Resource Management, 39(2), 3.

30. Ostrowski, Paul S. (1968). "Prerequisites for Effective Succession". Management of Personnel Quarterly, 7(1), 10-16.

31. Patton, James R. (2001). “Succession Planning: Building Bench Strength”. Hoosier Banker, 85(5), $18-21$.

32. Pernick, Robert, (2001). "Creating a Leadership Development Program: Nine Essential Tasks". Public Personnel Management, 30(4), 429-444.

33. Rollins, Gina. (2003). "Succession planning: Laying the foundation for smooth transition and effective leaders". Healthcare Executive, 18(6), 14-20.

34. Rothwell, William J. (2002). "Putting success into your succession planning". The Journal of Business Strategy, 23(3), 32-37.

35. Rothwell, William, and Wellins, Rich. (2004). "Mapping Your Future: Putting New Competencies to Work For you". Training and Development, 58(5), 94-100.

36. Saldarini, Katy. (2000). "An emerging crisis”. Government Executive, 32(8), 109.

37. Schall, Ellen. (1997). "Public-Sector Succession: A Strategic Approach to Sustaining Innovation”. Public Administration Review, 57(1), 4-10.

38. Stoney, Christopher. "Partnership and workplace learning in the UK: Pioneering work at British Telecommunications plc". Journal of Workplace Learning, 14(1/2), 50-67.

39. Stringer, Robert A., and Cheloha, Randall S. (2003). "The Power of a Development Plan". Human Resource Planning, 26(4), 10-17.

40. Tansky, Judith W., Cohen, and Debra, J. (2001). "The Relationship Between Organizational Support, Employee Development, and Organizational Commitment: An Empirical Study". Human Resource Development Quarterly, 12(3), 285-300.

41. Wallum, Peter. (1993). “A Broader View of Succession Planning”. Personnel management, 25(9), $42-45$. 


\section{NOTES}

